\author{
BILJANA B. RADIĆ-BOJANIĆ \\ JAGODA P. TOPALOV ${ }^{2}$ \\ UNIVERSITY OF NOVI SAD \\ FACULTY OF PHILOSOPHY \\ DEPARTMENT OF ENGLISH STUDIES
}

\title{
TEXTBOOKS IN THE EFL CLASSROOM: DEFINING, ASSESSING AND ANALYZING ${ }^{3}$
}

\begin{abstract}
The aim of this paper is to define textbooks, analyze their advantages and disadvantages and to explicate the process of textbook selection and reasons for analyzing textbooks. The paper describes two reasons for performing a textbook analysis: evaluating for potential and evaluating for suitability, and further states various processes of textbook content analysis including the analysis of the stated aims and objectives, learner needs, their abilities and preferences, as well as the establishment of criteria in relation to previously set objectives. The paper concludes by stating that the task that teachers are faced with when selecting and evaluating textbooks is not that is an easy one, but it is crucial. With the assistance of clear guidelines and detailed criteria, they should be able to make an informed decision and choose a textbook that is most suitable for the requirements of their specific classroom context.
\end{abstract}

KEY WORDS: textbook, assessing, evaluating for potential, evaluating for suitability, selection criteria.

\footnotetext{
radic.bojanic@ff.uns.ac.rs

jagoda.topalov@ff.uns.ac.rs

3 The paper is the result of research conducted within project no. 178002 "Languages and cultures across time and space" funded by the Ministry of Education and Science of Republic Serbia.

This paper was submitted on September 2, 2016 and accepted for publication at the meeting of the Editorial Board held on September 29, 2016.
} 


\section{INTRODUCTION}

Textbooks are undoubtedly the most popular teaching materials used in foreign language classes. Therefore, it is highly significant that textbooks include the essential elements of language and culture and that they correspond to learners' needs, cultural background and level of linguistic proficiency. Accordingly, it is vitally important to help teachers choose the most appropriate ones for their classes.

This paper aims at defining textbooks and presenting advantages and disadvantages of using them in class. Moreover, it sheds light on the process of selecting textbooks and reasons for analyzing textbooks.

\section{DEFINING TEXTBOOKS}

According to Oxford Advanced Learner's Dictionary, a textbook is defined as "a book that teaches a particular subject and that is used especially in schools and colleges" (OALD, 2000, p. 1238). In accordance with the given definition, EFL textbooks aim at providing learners with necessary knowledge, language skills and information about English speaking countries and preparing them for interaction with people from foreign countries and of different cultural backgrounds. Textbooks usually combine contemporary and traditional approaches to language teaching. They incorporate concepts such as 'learner development', a 'task-based methodology', and 'cross-curricular themes' while providing a grammar framework and a thorough practice of vocabulary, grammatical structures and functions (Hutchinson \& Gault, 2009, p. 4). They have been primary teaching instruments for most students since the $19^{\text {th }}$ century.

Hutchinson and Torres (1994, p. 315) state that "the textbook is an almost universal element of (English language) teaching. Millions of copies are sold every year, and numerous aid projects have been set up to produce them in (various) countries... No teaching-learning situation, it seems, is complete until it has its relevant textbook." Sheldon $(1988$, p. 237) argues that textbooks symbolize "the visible heart of any ELT program" and they offer significant 
advantages for both students and teachers. In his view, students' opinion is that published materials (textbooks) are more trusted than home-produced photocopied teachers' resources, which are regarded as less valid. Their view is based on the fact that textbooks are written by eminent experts in the field of language teaching. The effects of using a particular textbook, therefore, depend not only on its promoted approaches and methods and its content, but also on the expectations of the learners and the general view of textbooks in the learners' culture.

Cortazzi and Jin (1999) refer to a textbook as a teacher, a map, a resource, a trainer and an authority. As a teacher, a textbook gives students relevant information about grammar and vocabulary, as well as English speaking countries and their cultures. As a map, it shows an outline of linguistic and cultural elements as a structured programme and it guides students and teachers to follow the steps taken in previous lessons. A textbook is viewed as a resource as it contains a set of materials and activities available to the teacher from which one can choose. It can also be a trainer for novice teachers who need valuable instructions, support and guidance. As an authority, a textbook is seen as valid, reliable, written by experts and authorized by important publishers or ministries of education.

In Cunningsworth's view $(1995$, p. 7), the roles of textbooks are identified as:

- an effective resource for self-directed learning and self-study;

- a valuable resource for presentation material (written and spoken);

- a source of ideas and activities for learner practice and communicative interaction;

- a reference source for students;

- a syllabus;

- a support for less experienced teachers to gain confidence and demonstrate new methodologies.

In addition to that, he claims that

"no course book will be totally suited to a particular teaching situation. The teacher will have to find his own way of using it and adapting it if necessary. So we should not be looking for the perfect course book which meets all our requirements, but rather for the best possible fit between what the course book offers and what we as teachers and our students need" (Cunningsworth, 1984, p. 6). 
Hutchinson and Torres (1994) refer to textbooks as effective agents of change, playing a significant role in innovation. They indicate that textbooks introduce change gradually within a structured framework and create a supportive environment for teachers in potentially disturbing change processes, helping them to feel more confident to demonstrate new methodologies and relieving them from the burden of responsibility for introducing change. They argue that textbooks have a vital importance in teaching the English language, especially at an elementary level, and they become even more important in periods of change. Gray (2000) defines textbooks as "ambassadorial cultural artifacts" (Gray qtd. in Litz, 2005, p. 7) and says that students can improve their language skills by using them as a useful means in order to stimulate discussions and cultural arguments.

\section{ADVANTAGES AND DISADVANTAGES OF USING TEXTBOOKS}

EFL textbooks cause a number of reactions, which often oscillate between two extremes, representing arguments and counterarguments for textbook usage in the classroom.

Well-known linguists and authors such as Sheldon (1988), Hutchinson and Torres (1994), Cunningsworth (1995), Cortazzi and Jin (1999) and others share the opinion that textbooks are necessary tools for language teaching and learning. On the one hand, they help students improve their language skills, learn about the subject content, and become familiarized with the cultures and way of life of people from foreign countries. On the other hand, textbooks can help teachers as well, serving as a teaching programme and a support for less experienced ones to gain confidence, test new methodologies, and become aware of the pedagogical issues.

Researchers such as Allwright (1981), Porreca (1984), Cathcart (1989), Clarke and Clarke (1990), Carrell and Korwitz (1994) and Renner (1997) express contrary views, arguing that textbooks lack authentic texts since they depict preferences and biases of their authors and therefore may generate misjudgement, misconceptions, prejudices and stereotypical representations of people from other countries. In their view, such teaching materials are not suitable and convenient for classroom usage. 
In addition to the above mentioned groups of linguists, there are a number of authors whose attitude towards textbook usage lies somewhere between the two extremes (e.g. O'Neill, 1982; Prodromou, 1988; Alptekin, 1993; Graves, 2000; Harmer, 2001). They claim that textbooks represent merely a framework for one's teaching, which can be reinforced by additional materials based on the needs and preferences of a specific group of students.

The majority of teachers feel secure using a textbook as a basis for their lesson plans. They consider it convenient to have a textbook as a teaching aid since the texts and tasks provide a sense of security about what should be taught in class. Textbooks and instructional materials should aim at raising novice teachers' awareness of pedagogical issues. Less experienced teachers can use the textbook as a framework of reference as they slowly become more attentive to individual student needs. With time they can introduce more variety in the materials they use and the techniques they employ. According to Eisner (1987, p. 12), not only does a textbook define a considerable amount of the content, arrangement and aims of the curriculum, but it also influences the way in which certain topics are presented. Allwright (1981, p. 8) argues that language learning is such a complex process that textbooks cannot meet various needs of learners around the world. There is no perfect textbook that meets the needs of all students, teachers, schools and curricula. Each textbook has its own strengths and weaknesses and, consequently, no textbook designed for general market can be perfectly suitable for a specific group of learners. Teachers' opinion on the same textbook may differ depending on their experience, background, teaching styles and the needs of their students. In Graves' view (2000, p. 175), "what one teacher considers an advantage in a textbook, another teacher may consider a disadvantage."

Most teachers have traditionally been taught to view a textbook as an end product, instead of a starting point for their teaching. According to O'Neill (1982, p. 110), textbooks provide only a core or a base of materials, a jumping-off point for a teacher and their class. They can serve as a grammatical and functional framework which leaves enough space for improvization, adaptation and a spontaneous and creative interaction in the classroom. Using a textbook reduces the chance of gaps in learning and the learner is always certain where the course is going, since there is a clear structure from the beginning to the end. In Harmer's view (2001, p. 
8), textbooks are merely proposals for action, not instructions for use. Teachers should look at the proposals and decide whether they agree with them or not.

On the other hand, Allwright (1981, p. 9-10) claims that textbooks are too rigid and they mirror the pedagogic, psychological and linguistic predilections and biases of their authors. Textbooks impose, determine and control language learning and teaching methods, techniques, approaches, procedures and processes. The advocates of authentic language in the classroom such as Cathcart (1989) argue that besides cultural and social biases, the representation of the target language in textbooks is unnatural, inappropriate and unauthentic and such language models and dialogues do not prepare students satisfactorily for real-life situations. In their view, textbooks give unrealistic representations of real-life situations as they contain relatively few examples of authentic texts and dialogues (Cathcart, 1989). Furthermore, such a view might lead to misconceptions regarding the target society and its culture and might be dangerous for those who expect to interact with native speakers on a regular basis. The authors and researchers such as Porreca (1984), Florent and Walter (1989), Clarke and Clarke (1990), Carrell and Korwitz (1994) and Renner (1997) consider textbooks to be socially and culturally biased as they contain evident examples of sexism, stereotyping and gender bias, specifically in terms of sexist and unrealistic characterization of both men and women, under-representation and disregard of female characters and stereotypes regarding occupations, relationships, actions and roles in society (Porreca, 1984; Florent \& Walter, 1989; Clarke \& Clarke, 1990; Carrell \& Korwitz, 1994; Renner, 1997). Prodromou (1988) and Alptekin (1993) consider target language culture to be a vehicle for teaching the language in textbooks and they claim that it is not possible to teach a language without embedding its cultural base. They argue that such a process impels learners to express themselves within a culture they know very little about, which may cause stereotyping, prejudices, misconceptions and sometimes unwillingness to learn. In Alptekin's view (1993, p. 138), most textbook writers are native speakers who consciously or subconsciously impart the values, beliefs, attitudes, views and feelings of their own English-speaking society. It is crucial, therefore, that teachers develop their own critical thinking and intercultural competence in order to be able to deal with potential cultural conflicts and stereotypical presentations in textbooks. As the 
majority of a country's culture is for the most part invisible, present in seemingly unmarked everyday interactions, a teacher's responsibility goes beyond that of the textbook's author, as only the teacher can mediate between the text and the specific culture within the classroom.

In order to avoid prevalent bad sides and disadvantages of instructional materials, it is necessary to carry out a systematic analysis of textbooks based on well-established criteria and determine their strengths and weaknesses. Experts such as Joiner (1974), Sheldon (1988), Skierso (1991), Cunningsworth (1984, 1995), Byram (1997), Byrd (2001), Brown (2001) and Kilickaya (2004) have provided various manuals and checklists for textbook analysis, from which a teacher can choose according to one's needs and preferences.

\section{REASONS FOR TEXTBOOK ANALYSIS}

Textbook analysis can be carried out in two directions: the analysis of selected textbooks in order to determine whether they are suitable or not for classroom usage, i.e. predictive analysis, and the analysis of textbooks that are already in use, i.e. retrospective analysis (Skopinskaja, 2003, p. 39). Using a slightly different terminology, Cunningsworth (1995, p. 15) describes how textbooks can be evaluated for potential and for suitability. In the first case, the textbook is assessed according to a predefined set of criteria, but without any particular learners or courses in mind. This approach is more frequent when a new textbook is published and may result in book reviews being written. However, since classroom situations introduce many unknown elements and require constant adapting on the side of the teacher, this type of analysis has its flaws as the textbook cannot be matched to a particular class or group of students. On the other hand, the evaluation of textbooks for suitability is always done with a certain audience in mind. In this case, as Cunningsworth $(1995$, p. 15) stipulates, there are very specific learning objectives, learners' backgrounds, resources available, etc. In practice, it can be said that both types of analysis are done equally frequently and sometimes the same textbook is analyzed first for potential (before it is used in class, as the teacher is selecting a textbook for the upcoming academic year) and then for suitability (while it is used in class, so the teacher can confirm 
that the choice he/she made was correct). In case the textbook is assessed positively in both of these situations, then it will be used in future; in case the evaluation for suitability proves that the textbook does not comply with all the needs of the learners, then the teacher has a clear signal that another textbook should be chosen. of course, a variety of other factors such as school policy, contracts with publishers, etc. make the switching of the textbook difficult or impossible, but that is beyond the scope of this paper.

\section{CRITERIA FOR TEXTBOOK ANALYSIS}

Textbook analysis is not an easy task as it includes several processes. Firstly, textbook content needs to be analyzed in reference to its specified aims and objectives, e.g. to what extent teaching areas like grammar, vocabulary, reading and writing and culture is present in a student's book, teachers' manual and activity book. In addition, it is important to determine whether, for example, cultural information is taught in a particular context (texts, exercises, dialogues) or as isolated facts. Secondly, textbook content should be examined in terms of learners' needs, abilities and preferences. Thirdly, the criteria of analysis need to be established in relation to previously set objectives, e.g. to determine to what extent cultural content matches the suggested criteria of textbook analysis (Skopinskaja, 2003, p. 44).

Saville-Troike (1982, p. 8) suggests a combination of quantitative and qualitative methods of content analysis. In her view, "qualitative and quantitative to the study of culturally situated communication are not mutually exclusive, and each can and should inform the other."

Although Fraenkel (1996) and Saville-Troike (1982) suggest that content analysis in textbooks is objective and reliable, Sheldon $(1988$, p. 245) argues that "it is clear that textbook assessment is fundamentally a subjective, rule-of-thumb activity, and that no neat formula, grid or system will ever provide a definite yardstick". In his view, establishing uniform evaluative criteria might help to make textbook analysis more objective than it is at present. Furthermore, a retrospective analysis may test the validity of a predictive analysis and point out which steps should be taken to improve it (Skopinskaja, 2003, p. 43). 
Quantitative analysis is defined as 'a type of research where the results are shown in the form of numbers or percentages' (Longman Business English Dictionary, 2000, p. 411). A quantitative analysis is a study in which a researcher applies scientific procedures in order to discover the answers to his/her questions, examining measurable and verifiable data. Various procedures are applied in order to reduce the possibility of partial and irrelevant answers to the questions asked and to increase the probability of relevant and impartial information (Perez Sanchez, 2011, p. 27).

However, in practice most teachers do not have time to conduct a detailed quantitative analysis of textbooks, either for potential or for suitability, even if they follow a set of criteria. This type of analysis is done much more frequently by researchers who are looking to assess various approaches in, for example, teaching grammar, vocabulary, skills, elements of culture, etc. The type of analysis that in-service teachers resort to much more often is qualitative analysis, which is addressed in the next section.

QUALITATIVE ANALYSIS

Qualitative analysis is defined as "a type of research that aims to find out people's attitudes or opinions about something, where the results cannot be shown in numbers" (Longman Business English Dictionary, 2000, p. 411). This method is used to investigate the reasons and modes of decision making while the data obtained describe certain types of information (Perez Sanchez, 2011, p. 27). Textbook evaluation checklists are often used as the criteria of qualitative analysis.

The literature on textbook analysis offers a number of checklists as evaluation criteria suggested by authors such as Joiner (1974), Cunningsworth (1984), Sheldon (1988), Skierso (1991), Byram (1994), Brown (2001) and Kilickaya (2004). They agree that evaluation checklists should have criteria referring to the physical characteristics of textbooks such as layout, logistical and organizational features, as well as those referring to methodology, aims, approaches to teaching and cultural information.

Cunningsworth (1995, p. 15-17) proposes four guidelines of textbook evaluation, according to which an evaluation checklist was developed: 
1) textbooks need to match the objectives of language learning programme and they should correspond to learners' needs;

2) textbooks should be chosen to help students use the language effectively for their own purposes;

3) textbooks should facilitate the learning process without imposing 'rigid' learning methods;

4) textbooks should mediate between learners and the target language thus supporting the learning process.

Cunningsworth's checklist (1995) comprises eight main categories: aims and approaches, design and organization, language content, methodology, skills, topic, teachers' books and other practical considerations. Each category contains four to seven checking items. Moreover, Cunningsworth suggests two approaches to textbook analysis, an in-depth approach and an impressionistic evaluation. On the one hand, an in-depth approach is used to determine how particular features of textbooks are dealt with, such as syllabus requirements, learners' needs, teachers' role, aspects of language, etc. This approach uses a comprehensive checklist as a tool for analysis. On the other hand, an impressionistic evaluation is used as a preliminary step to determine whether a selected textbook is suitable or not before a detailed analysis is carried out. In his view, a combination of both approaches would be most effective.

Sheldon's evaluation guide (1988, p. 242) contains seventeen categories of suggested textbook criteria: rationale, availability, user definition, layout/graphics, accessibility, linkage, selection/ grading, physical characteristics, appropriacy, authenticity, sufficiency, cultural bias, educational validity, stimulus/practice/ revision, flexibility, guidance and overall value for money. Each category contains two to seven questions that represent "some points around which our thoughts can crystallize" (Sheldon, 1998, p. 242). His checklist is focused on text authenticity, appropriateness and cultural bias, pointing out that teachers should pay attention to stereotypes, misconceptions and offensive images regarding gender, race, nationality and social class in textbooks. Sheldon explores cultural and social topics further, asking if the views of Great Britain and the USA are realistic or difficult social topics such as poverty, unemployment, racism, and family breakdowns are left out. In his view, judging by the same criteria, the same textbook could be rated as 'successful' in one context, but not 
in another. The rating depends on a teacher who carries out the analysis and on his/her preferences and subjective judgement, and there are no evaluative parameters that would be supported by all teachers.

Skierso's checklist (1991, p. 444-452) is certainly the longest and the most encompassing one covered by the literature on textbook analysis. The updated version is eight pages long and certain sections and topics for consideration are used and modified by other authors. Skierso identifies a number of elements that need to be determined before the analysis is carried out, which contain necessary information on students, teachers and the educational institutions. She supports Cunningworth's idea (1995) of an impressionistic evaluation or first-glance evaluation as a survey that could help eliminate inappropriate or unsuitable textbooks from the selection process (Skierso, 1991, p. 435).

Brown (2001, p. 142) suggests an evaluation form that can be used as a practical set of criteria for either choosing a textbook for a course or evaluating the textbook that is currently used. In his view, it is necessary to carry out a thorough evaluation procedure in order to choose a textbook that completely meets the established evaluation criteria. Brown's checklist consists of twelve categories that contain one to seven topics for consideration. The categories in the checklist include mostly general criteria of analyzing textbook content, such as:

- goals of the course;

- background of the students (age, native language and culture, educational background, motivation or purpose for learning English);

- theoretical approach (theory of learning and theory of language);

- language skills (listening, speaking, reading and writing);

- quality of practice material (explanations, clarity of directions and active participation of students);

- sequencing (by grammatical structures, skills, situations or by some combination of the above);

- vocabulary (relevance, frequency and strategies for word analysis);

- format (clarity of typesetting, use of special notation (phonetic symbols, stress/intonation marking), quality and clarity of 
illustrations, general layout, size of the book and binding, quality of editing, index, table of contents and chapter headings);

- supplementary materials (workbook, audio and video tapes, posters, flashcards, a set of tests);

- teacher's guide (methodological guidance, alternative and supplementary exercises, suitability for non-native speaking teacher and answer keys) (Brown, 2001, p. 142).

Brown's checklist (2001) is regarded as the most comprehensive one by many as it includes both general and specific criteria of textbook analysis and it covers a variety of factors important in foreign language teaching.

CONCLUSION Within the state school system, teachers are not properly trained how to choose, adapt, evaluate and use the textbooks according to their students' needs. For that reason, the textbook selection process becomes one of the most challenging tasks for them. Most state schools in Serbia choose textbooks based on what is offered and made available by well-known publishers. However, this process of preparation, selection, approval and publishing textbooks is regulated by the Law on Textbooks and Other Teaching Resources (2015). Textbook series used in schools in Serbia need to be published and approved in accordance with the Law and textbook publishers have to obtain a publishing licence issued by the Ministry of Education, Science and Technological Development. The Minister of Education gives approval of textbooks guided by the suggestion of the National Education Council, which is based on expert assessment of textbook quality provided by the Institute for Educational Development. The register of approved textbooks for the upcoming school years is published in the catalogue of the Ministry of Education and the choice of particular textbooks for every school subject is put in the hands of the Teachers' Councils in each school. Therefore, it is necessary to educate teachers how to choose the most appropriate textbooks for their students, since the final step of the selection process is based on their own judgement.

Since 1970s there has been a change of perspective regarding the teaching and learning methods and techniques, which has put the learner in the centre of the educational process. Therefore, it is best to consider textbooks as aids for achieving goals and objectives 
that have already been determined by learner needs. According to Brown (2001, p. 137), textbooks should always be 'at service' of teachers and learners although they do not necessarily set the teaching and learning goals. For that reason the teachers' task is to establish a variety of criteria for textbook analysis in order to select the most appropriate ones for classroom usage that will fulfill the students' needs. Sheldon (1988, p. 237) states that the selection of a textbook indicates a significant "administrative and educational decision in which there is considerable professional, financial and even political investment" and therefore it is of vital importance to establish the criteria of textbook analysis. Moreover, the analysis would help the teachers to recognize the strengths and weaknesses of the textbook which is already in use. The selected textbook should suit the goals, aims, methods and approaches of the language syllabus. According to Cunningsworth (1995, p 7), one should make sure that "careful selection is made, and that the materials selected closely reflect (the needs of the learners and) the aims, methods, and values of the teaching program". Similarly, textbook analysis may help teachers to gain an accurate and systematic insight into the overall nature of textbook material, serving as a means of research on the topic thus giving them the opportunity for personal growth and professional development.

REFERENCES Aliakbari, M. (2004). The place of culture in the Iranian textbooks in high school level. The Linguistic Journal 1, 1-14.

Allwright, R. (1981).What do we want teaching materials for? ELT Journal 36 (1), 5-18.

Alptekin, C. (1993). Target-language culture in EFL materials. ELT Journal 47 (2), 136-143.

Brown, H. D. (2001). Teaching by principles: an interactive approach to language pedagogy. White Plains, NY: Longman.

Byram, M. (1997). Teaching and assessing intercultural communicative competence. Clevedon: Multilingual Matters.

Byrd, P. (2001). “Textbooks: evaluation for selection and analysis for implementation". In: M. Celce-Murcia (ed.), Teaching English as a second or foreign language (pp. 415-427). Boston: Heinle and Heinle.

Carrell, D., \& J. Korwitz. (1994). “Using concordancing techniques to study gender stereotyping in ELT textbooks". In: J. Sunderland (ed.), Exploring Gender: Questions and Implications for English Language Education (pp. 73-82). Hemel Hempstead: Prentice Hall. 
Cathcart, R. (1989). Authentic discourse and the survival English curriculum. TESOL Quarterly 23, 105-126.

Clarke, J., \& M. Clarke. (1990). "Stereotyping in TESOL materials". In: B. Harrison (ed.), Culture and the Language Classroom (pp. 31-44). Hong Kong: Modern English Publications/British Council.

Cortazzi, M., \& Jin, L. (1999). "Cultural mirrors materials and methods in the EFL classroom". In: E. Hinkel (ed.), Culture in second language teaching and learning (pp. 196-219). Cambridge: Cambridge University Press.

Cunningsworth, A. (1984). Evaluating and selecting EFL teaching materials. Oxford: Heinemann Publishers Ltd.

Cunningsworth, A. (1995). Choosing your coursebook. Oxford: Macmillan Heinemann ELT.

Dignen, S. (ed.). (2000). Longman business English dictionary. Harlow: Pearson Education Limited.

Eisner, E. (1987). Why the textbook influences curriculum. Curriculum Review 26 (3), 11-13.

Florent, J., \& Walter, C. (1989). A better role for women in TEFL. ELT Journal 43 (3), 180-184.

Frankael, J. (1996). How to design and evaluate research in education. New York: McGraw Hill, Inc.

Graves, K. (2000). Designing language courses. Boston: Heinle \& Heinle Publishers.

Harmer, J. (1991). The practice of English language teaching. London: Longman.

Hutchinson, T., \& Torres, E. (1994). The textbook as agent of change. ELT Journal 48 (4), 315-328.

Hutchinson, T., \& Gault, J. (2009). Project 5: Teacher's book (3rd ed.). Oxford: Oxford University Press.

Inal, B. (2006). Coursebook selection process and some of the most important criteria to be taken into consideration in foreign language teaching. Journal of Arts and Sciences 5 (5), 19-29.

Joiner, E. G. (1974). Evaluating the cultural content of foreign language texts. The Modern Language Journal 48 (5), 242-244.

Kilickaya, F. (2004). Guidelines to evaluate cultural content in textbooks. The Internet TESL Journal, 10 (12). Retrieved from http://iteslj.org/Techniques/Kilickaya-CulturalContent/ (26 Sept 2016)

Litz, D. R. A. (2005). Textbook evaluation and ELT management: A South Korean case study. Asian EFL Journal, 1-53. 
Hornby, A. S., Wehmeier, S., \& Ashby, M. (eds.). (2000). Oxford Advanced Learner's Dictionary of Current English (6th ed.). Oxford: Oxford University Press.

O’Neill, R. (1982). Why use textbooks? ELT Journal 36 (2), 104-111.

Perez-Sanchez, I. (2011). The importance of culture when learning the English language through the Upstream Intermediate textbook. Licenciatura en Lengua Inglesa, Language Department, Universidad Veracruzana, Veracruz, Mexico.

Porreca, K. (1984). Sexism in current ESL textbooks. TESOL Quarterly 18 (4), 705-724.

Prodromou, L. (1988). English as cultural action. ELT Journal 42 (2), 73-83.

Renner, C. (1997). Women are 'busy, tall, and beautiful': looking at sexism in EFL materials. Annual Meeting of the Teachers of English to Speakers of Other Languages. Orlando Fl., March 11-15. Retrieved from http://files. eric.ed.gov/fulltext/ED411670.pdf (26 Sept 2016)

Saville-Troike, M. (1982). The ethnography of communication: an introduction. Oxford: Basic Blackwell.

Sheldon, L. (1988). Evaluating ELT textbooks and materials. ELT Journal 42(2), 237-246.

Skierso, A. (1991). “Textbook selection and evaluation”. In: M. Celce-Murcia (ed.), Teaching English as a second or foreign language (pp. 432-453). Boston: Heinle and Heinle.

Skopinskaja, L. (2003). "The role of culture in foreign language teaching materials: An evaluation from an intercultural perspective”. In: I. Lázár (ed.), Incorporating intercultural communicative competence in language teacher education (pp. 39-68). European Centre for Modern Languages, Council of Europe Publishing. Retrieved from: http://archive.ecml.at/documents/ pub123bE2003_Lazar.pdf (26 Sept 2016)

Yen, Y. Y. (2000). Identity issues in EFL and ESL textbooks: A sociocultural perspective. PhD dissertation. Ohio State University, Columbus Department of Philosophy.

Закон о уџбеницима и другим наставним средствима. (2015). Retrieved from http://www.mpn.gov.rs/wp-content/uploads/2015/08/Закон-о-уџठе ницима.pdf (26 Sept 2016) 
БИљАНА Б. РАДИЋ-БОЈАНИЋ

ЈАГОДА П. ТОПАЛОВ

УНИВЕРЗИТЕТ У НОВОМ САДУ

ФИЛОЗОФСКИ ФАКУЛТЕТ

ОДСЕК ЗА АНГЛИСТИКУ

РЕЗИМЕ

\author{
УЏБЕНИЦИ У НАСТАВИ ЕНГЛЕСКОГ ЈЕЗИКА: \\ ДЕФИНИСАЮЕ, ОЦЕЊИВАЬЕ И АНАЛИЗИРАЮЕ
}

Циљ рада јесте да дефинише уџбенике и анализира предности и мане њиховог коришћења у настави страног језика, као и да представи процес одабира уџбеника и разлоге за њихову анализу. У раду се најпре дају дефиниције уџбеника из перспективе кључних аутора у овој области и интерпретирају се њихови приступи, а затим се уџбеници анализирају спрам потенцијалних улога које имају у настави страног језика. Рад се даље усмерава ка тумачењу предности и мана коришћења уџбеника у настави и наглашава се тренутно најутицајнији став у литератури и пракси према којем уџбенике треба посматрати као референтни оквир и почетну тачку за планирање часова и извођење наставе. Пажња се даље усмерава ка принципима анализе уџбеника и наводе се два основна разлога због којих се ова анализе врши: анализа потенцијала уџбеника, која се врши како би се установило у каквим контекстима и са каквим ученицима би уџбеник могао да се користи, као и анализа усклађености, која се врши како би се утврдило да ли одређен уџбеник одговара потребама конкретних ученика за које се уџбеник бира. У раду се даље наводи да анализа уџбеника подразумева неколико процеса међу којима су анализа наведених циљева, потреба ученика, њихових способности и склоности, као и анализа усклађености са претходно постављеним циљевима. У складу с тим, даје се кратак преглед две истраживачке парадигме према којима се анализа врши: квантитативне и квалитативне. На основу дефиниција, описаног процеса процењивања и одабира уџбеника, може се закључити да је у питању задатак који наставницима страног језика није нимало лак због чега је неопходно да за то буду адекватно обучени и припремљени. Имајући у виду предности и мане уџбеника који процењују, индивидуалне потребе, стилове, способности и потребе својих ученика, али и циљну културу која се у уџбеницима представља у мери која је мање или више објективна, наставници би, уз коришћење јасних смерница и детаљних критеријума требало 
да донесу праву одлуку и одаберу уџбеник који у највећој мери одговара конкретним захтевима присутним у настави страног језика.

Кључне речи: уџбеник, оцењивање, анализа потенцијала, анализа усклађености, критеријуми за одабир. 